\title{
Geologic map of the Telegraph Peak 7.5' quadrangle, San Bernardino County, California
}

\author{
By D.M. Morton ${ }^{1}$, M.O. Woodburne ${ }^{2}$ and J.H. Foster ${ }^{3}$ \\ Digital preparation by Gregory Morton ${ }^{1}$ and P.M. Cossette ${ }^{4}$ \\ Prepared in cooperation with \\ CALIFORNIA DIVISION OF MINES AND GEOLOGY
}

Open-File Report OF 01-293

2001

Any use of trade, product, or firm names is for descriptive purposes only and does not imply endorsement by the U. S. Government. This database, identified as "Geologic map of the Telegraph Peak 7.5' quadrangle, San Bernardino County, California " has been approved for release and publication by the Director of the USGS.

\section{U. S. DEPARTMENT OF THE INTERIOR}

U. S. GEOLOGICAL SURVEY

${ }^{1}$ U.S. Geological Survey, Department of Earth Sciences, University of California, Riverside, CA 92521

${ }^{2}$ University of California, Riverside, CA 92521

${ }^{3}$ California State University, Fullerton, CA 92834

${ }^{4}$ Western Earth Surface Processes Team, U.S. Geological Survey

904 West Riverside Avenue, Room 202, Spokane, WA 99208-1087 


\section{TABLE OF CONTENTS}

Introduction

General

How to obtain paper plots

Database contents

Data package

Plot package

Other files

Software utilities

How to obtain the digital files

How to extract the geologic map database from the tar file

Digital database

PostScript plot files

Portable Document Format (.pdf) files

How to convert the ARC/INFO interchange (export) files

Digital geologic map specifications

Digital and geologic compilation of geologic map

Base map

Spatial resolution

Map accuracy standards

Database specifics

General

Lines

Polygons

Points

References

\section{INTRODUCTION}

\section{General}

Open-File Report OF 01-293 contains a digital geologic map database of the Telegraph Peak 7.5' quadrangle, San Bernardino County, California that includes:

1. ARC/INFO (Environmental Systems Research Institute, http://www.esri.com) version 7.2.1 double precision coverages of the various elements of the geologic map.

2. A PostScript file to plot the geologic map on a topographic base, and containing a Correlation of Map Units diagram, a Description of Map Units, an index map, and a regional structure map.

3. Portable Document Format (.pdf) files of:

a. This Readme; includes in Appendix I, data contained in fif_met.txt

b. The same graphic as plotted in 2 above. Test plots have not produced 1:24,000-scale map sheets. Adobe Acrobat pagesize setting influences map scale.

The Correlation of Map Units and Description of Map Units is in the editorial format of USGS Miscellaneous Investigations Series (I-series) maps but has not been edited to comply with I-map standards. Within the geologic map data package, map units are identified by standard geologic map criteria such as formation-name, age, and lithology. Even though this is an author-prepared report, every attempt has been made to closely adhere to the stratigraphic nomenclature of the U. S. Geological Survey. Descriptions of units can be obtained by viewing or plotting the .pdf file ( $3 \mathrm{~b}$ above) or plotting the postscript file ( 2 above). If roads in some areas, especially forest roads that parallel topographic contours, do not show well on plots of the geologic map, we recommend use of the USGS Telegraph Peak 7.5 ' topographic quadrangle in conjunction with the geologic map. 
This README file describes the digital data, such as types and general contents of files making up the database, and includes information on how to extract and plot the map and accompanying graphic file. Metadata information can be accessed at http://geo-nsdi.er.usgs.gov/cgi-bin/publication?map-of and is included in Appendix I, Readme.

\section{HOW TO OBTAIN PAPER PLOTS}

For those having access to large-format plotters such as HP650C, HP755C, and HP2500C, plots may be made directly from the included plot file.

\section{DATABASE CONTENTS}

The files constituting the geologic map database of this Open-File Report are listed below along with the interchange files from which they are extracted.

\section{Data Package}

All files listed below are in a compressed tar file named tel.tar.gz (3MB); see section below titled, SOFTWARE UTILITIES.

\begin{tabular}{|c|c|c|}
\hline $\begin{array}{l}\text { ARC/INFO } \\
\text { interchange files }\end{array}$ & $\frac{\text { Fifteenmile Valley }}{\underline{\text { files }}}$ & $\underline{\text { Contains }}$ \\
\hline tel_geo.e00 & tel_geo & $\begin{array}{l}\text { Contacts, faults, geologic unit } \\
\text { labels }\end{array}$ \\
\hline & tel_str & $\begin{array}{l}\text { Attitudes and their dip or plunge values. Dip } \\
\text { or plunge values plotted as annotation. }\end{array}$ \\
\hline tel_ldr.e00 & tel_ldr & unit label leaders \\
\hline $\begin{array}{l}\text { lines.rel.e00 } \\
\text { points.rel.e00 } \\
\text { scamp2.shd.e00 }\end{array}$ & $\begin{array}{l}\text { lines.rel } \\
\text { points.rel } \\
\text { scamp2.shd }\end{array}$ & $\begin{array}{l}\text { Line dictionary } \\
\text { Point dictionary } \\
\text { SCAMP shade set }\end{array}$ \\
\hline
\end{tabular}

The directory, info/, is produced in the process of importing interchange files to ARC coverages in ARC/INFO. The tel (Telegraph Peak) info/ directory contains:

$\underline{\text { Feature Attribute tables }}$

Polygon attribute table

tel_geo.pat

Arc attribute tables

tel_geo.aat

tel_ldr.aat

Point attribute table

tel_str.pat

$\underline{\text { Additional tables }}$

lines.rel

points.rel
Dictionary, contains all SCAMP line codes (Matti and others, 1998a)

Dictionary, contains all SCAMP point codes (Matti and others, 1998b)

$\underline{\text { Raster file }} \quad \underline{\text { Resultant image }} \quad \underline{\text { Contains }}$ 
tel.tif

Telegraph Peak

base map
Topographic base from 500dpi scan of USGS

Telegraph Peak 7.5' quadrangle, 1971.

Geotiff format

\section{Plot Package}

PostScript plot files of the geologic map and CMU/DMU; please see section below titled, SOFTWARE UTILITIES for additional information.

\begin{tabular}{lll} 
Compressed file & $\underline{\text { Resultant image }}$ & $\underline{\text { Contains }}$ \\
\cline { 2 - 3 } & tel_map.ps & PostScript plot file of geologic map and \\
tel_map.ps.gz & CMU/DMU
\end{tabular}

PostScript files are compressed UNIX files requiring gzip to uncompress them.

The uncompressed PostScript file tel_map.ps will plot a 1:24,000 scale, full color geologic map of the Telegraph Peak quadrangle on a topographic base. A detailed CMU diagram, a DMU, and a regional structure map are included on the sheet. This sheet is in the editorial format of the U.S. Geological Survey's Miscellaneous Investigations (I) map series, and is approximately 45 X 32 inches in size. The map sheet has been successfully plotted on Hewlett-Packard large-format plotters, models HP650C, HP755CM, and HP2500C.

\section{Other files}
Readme.pdf
This document in .pdf format
tel_map.pdf
Geologic map, DMU, CMU, and sketch maps

\section{SOFTWARE UTILITIES}

Files which have .gz file extension were compressed using gzip. Gzip utilities are available free of charge via the internet at the gzip home page, http://www.gzip.org.

The data package is additionally bundled into a single tar (tape archive) file. Individual files must be extracted using a tar utility, available free of charge via the internet through links on the Common Internet File Formats page, http://www.matisse.net/files/formats.html. One such utility is WinZip, available at http://www.winzip.com (WinZip can also decompress files).

Files in the plot package have been prepared to produce optimum plots using the shade, and marker sets listed below. The marker, line and shade (pattern) sets may be obtained at the web site:

http://wrgis.wr.usgs.gov/docs/ncgm/scamp/scamp.html.

Geoage font group may be obtained at the following web site:
Server:
onyx.wr.usgs.gov
UserID:
anonymous
Password: Your e-mail address
Directory: pub/wpg/supplies/geoage

geoscamp2.lin
geoscamp2.mrk
scamp2.shd
geology2.shd
Geoage font group

Lines

Points

Colors (included in data package)

Patterns

Geologic Age Symbols 


\section{HOW TO OBTAIN THE DIGITAL FILES}

The export files, and subsequently the data and plot files, constituting the geologic map database of this Open-File Map may be obtained in two ways, both over the Internet.

1. The files can be obtained via the Web from Western Region Geologic Information Server. Go to the web page at http://geopubs.wr.usgs.gov/open-file/of01-293 and follow the directions to download the files.

2. The files can also be obtained by anonymous ftp over the Internet from wrgis.wr.usgs.gov. The files are located in the directory/pub/open-file/of01-293. Be sure to use binary transfer mode or ASCII mode for individual .e00 files (ARC interchange file format).

\section{HOW TO EXTRACT THE GEOLOGIC MAP DATABASE FROM THE TAR FILE}

After downloading the files, they must be uncompressed using a gzip utility such as gzip itself, Stuff It Expander or WinZip. The data files must then be extracted using a tar utility.

This process will create a directory, tel/, that contains the ARC/INFO interchange files and supporting files. The directory should contain the following files:

tel/

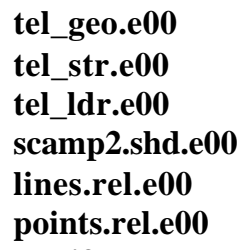

The following are not included in the database tar file, and are downloaded separately
Readme.pdf
This document in .pdf format
tel_map.pdf
Geologic map, DMU, CMU, and sketch maps

\section{PostScript plot files}

Make a 20 MB uncompressed file, tel_map.ps by typing gzip -d tel_map.ps.gz (or use gzip utility of choice).

\section{Portable Document Format (.pdf) files}

PDF files are not stored as gzip files. They are accessed using Adobe Acrobat Reader software, available free from the Adobe website http://www.adobe.com. Follow instructions at the website to download and install the software. Acrobat Reader contains an on-line manual and tutorial.

\section{HOW TO CONVERT THE ARC/INFO INTERCHANGE (EXPORT) FILES}

The ARC interchange (.e00) files are converted to ARC coverages using the ARC command IMPORT.

ARC interchange files can also be read by some other Geographic Information Systems, including ArcView (ESRI) and MapInfo (http://www.mapinfo.com) (Environmental Systems Research Institute, Inc, 1991). Please consult your GIS documentation to see if you can use ARC interchange files and the procedure to import them.

\section{DIGITAL GEOLOGIC MAP SPECIFICATIONS}

Digital and geologic compilation of geologic map 
The geologic map was compiled from 1:24,000 geologic mapping on aerial photographs and topographic quadrangle maps, transferred visually to a scale-stable cartographic base (scribeguide) of the Telegraph Peak 7.5' quadrangle. The scribe guide was used to make a 0.007 "-thick blackline, base-stable, clear-film from which the geologic map information was hand-digitized and subsequently edited.

\section{Base map}

The base map image (tel.tif, Geotiff format) was prepared by scanning a scale-stable clear film of the U.S Geological Survey, 1:24,000 Telegraph Peak 7. 5' quadrangle (1971) topographic map. Scanning was done using an Anatech Eagle 4080 monochrome 800 dpi scanner at a resolution of 500 dpi. The raster scan was converted to a monochromatic image in ARC/INFO, and registered and rectified to the Telegraph Peak 7.5' quadrangle. No elements of the base layer are attributed. The base map is provided for reference only.

\section{Spatial resolution}

Use of this digital geologic map database should not violate the spatial resolution of the data. Although the digital form of the data removes the constraint imposed by the scale of a paper map, the detail and accuracy inherent in map scale are also present in the digital data. The fact that this database was edited at a scale of 1:24,000 means that higher resolution information is not generally present in the dataset. Plotting at scales larger than 1:24,000 will not yield greater real detail, although it may reveal fine-scale irregularities above the intended resolution of the database. Similarly, although higher resolution data is incorporated at some places, the resolution of the combined output will be limited by the lower resolution data.

\section{Map accuracy standards}

Until uniform National geologic map accuracy standards are developed and adopted, lines and points on SCAMP 1:24,000 scale geologic maps that are located to within 15 meters, relative to accurately located features on the base map, are considered to meet map accuracy standards. Dashed lines, indicated in the database coding as not meeting map accuracy standards, are generally located to within 30 meters, relative to accurately located features on the base map.

\section{Database specifics}

General-The map database consists of ARC/INFO format double precision coverages which are stored in polyconic projection (Table 1), and a series of data tables. Digital tics define a 7.5-minute grid of latitude and longitude in the geologic coverages corresponding to the 7.5-minute tic grid on the topographic base map.

Table 1-Map Projection

\begin{tabular}{ll} 
Projection & Polyconic \\
Datum & NAD27 \\
Zunits & No \\
Units & Meters \\
Spheroid & Clark 1866 \\
X shift & 0.0000000000 \\
Y shift & 0.0000000000 \\
Parameters & -1173345.000 longitude of central meridian \\
34 15 00 latitude of projection's origin \\
\multicolumn{2}{l}{ 0.00000 false easting (meters) } \\
0.00000 false northing (meters)
\end{tabular}

The content of the geologic database can be described in terms of feature classes that include lines, points, and areas that comprise the map. See the metadata text file (Appendix I) for detailed descriptions. Although Version 1.0 of the Telegraph Peak 7.5' quadrangle does not contain coded, detailed, geologic attribute data, the items L-TAG (lines) and P-TAG (structural point data) do serve as relate items allowing users to establish a relate environment 
with and access to complete descriptions of the geologic entities contained in the line and point dictionaries (Matti and others, 1998a, 1998b). The following is an example of how to establish a simple relate environment and the

ARC/INFO dialogue the user will encounter:

At the Arc prompt, type: relate add

Dialogue for ADD

Relation name: alphanumeric name of relate you want to establish

Table identifier: pathname or database table name of the related file

Database name: name of the database in which the related file is stored

Info item:

Relate column:

Relate type:

the item name in an INFO data file from which the relate is performed

the field in the related table which is related to the INFO item

the type of relate performed-one of the following four: LINEAR,

ORDERED, LINK, TABLE. LINEAR is the slowest, but the simplest to

apply. (Please consult ARC/INFO online help topic such as 'working

with tables' for help on selection of relate type)

Relation access: the access rights to the related file: $\mathrm{RW}$, or RO, or AUTO

Example (lines):

Arc: relate add

Relation name: line_dictionary

Table identifier: lines.rel

Database name: info

INFO item: 1-tag

Relate column: 1-tag

Relate type: linear

Relate access: rw

Lines-Lines are recorded as strings of arcs and are described in an arc attribute (.aat) table. Complete lists of the line types (L-TAG) used in the quadrangle are available in Appendix I. They represent contacts and faults which define the boundaries of map units and map boundaries.

Polygons-Geologic map units (polygons) are described in the polygon attribute table (details inAppendix I). Using a system developed under the Southern California Areal Mapping Project (SCAMP), geologic maps can be encoded with detailed, polygon-specific geologic information on a polygon-by-polygon basis, so that within a quadrangle, lateral variations in a particular map unit can be recorded in the map database. Detailed encoding of polygons is not available in this version of the Telegraph Peak quadrangle, but will be in the next version. For traditional descriptions of the map units, see the Portable Document Format file tel_map.pdf or the Postscript map plot, tel_map.ps. A list of all map units in the database is given in Appendix I.

Points-Point information (attitudes of planar and linear features) is recorded as coordinate and related information. Complete lists of the point types (P-TAG) used in the point coverage are available in Appendix I.

\section{REFERENCES}

Environmental Systems Research Institute, Inc, 1991, ARC/INFO command references 6.0: Proprietary software manual.

Matti, J.C., Powell, R.E., Miller, F.K., Kennedy, S.A., Ruppert, K.R., Morton, G.L., and Cossette, P.M., 1998a, Geologic-line attributes for digital geologic map databases produced by the Southern California Areal Mapping Project (SCAMP), Version 1.0: U.S.Geological Survey Open-File Report 97-861. 
Matti, J.C., Miller, F.K., Powell, R.E., Kennedy, S.A., Bunyapanasarn, T.P., Koukladas, Catherine, Hauser, R.M., and Cossette, P.M., 1998b, Geologic-point attributes for digital geologic map databases produced by the Southern California Areal Mapping Project (SCAMP), Version 1.0: U.S.Geological Survey Open-File Report 97-859.

\author{
APPENDIX I \\ (Original metadata text) \\ Identification_Information: \\ Citation: \\ Citation_Information: \\ Originator: Douglas M. Morton \\ Originator: M.O. Woodburne \\ Originator: J.H. Foster \\ Publication_Date: 2001 \\ Title: Geologic Map of the Telegraph Peak 7.5' quadrangle, San Bernardino County, California \\ Edition: Version 1.0 \\ Geospatial_Data_Presentation_Form: vector digital data \\ Series_Information: \\ Series_Name: U.S. Geological Survey Open-File Report \\ Issue_Identification: USGS OF 01-293 \\ Publication_Information: \\ Publication_Place: Menlo Park, California \\ Publisher: U.S. Geological Survey \\ Online_Linkage: URL:http://geopubs.wr.usgs.gov/open-file/of01-293
}

Description:

\begin{abstract}
:
This data set maps and describes the geology of the Telegraph 7.5' quadrangle, San Bernardino County, California. Created using Environmental Systems Research Institute's ARC/INFO software, the data base consists of the following items: (1) a double precision map coverage containing geologic contacts and units, (2) a coverage containing site-specific structural data, (3) a coverage containing geologic-unit label leaders and their associated attribute tables for geologic units (polygons), contacts (arcs), and site-specific data (points). In addition, the data set includes the following graphic and text products: (1) A PostScript graphic plot-file containing the geologic map, topography, cultural data, a Correlation of Map Units (CMU) diagram, a Description of Map Units (DMU), an index map, a regional geologic and structure map, and a key for point and line symbols; (2) PDF files of this Readme (including the metadata file as an appendix), Description of Map Units (DMU), and the graphic produced by the PostScript plot file.
\end{abstract}

The Telegraph Peak quadrangle is located in the eastern San Gabriel Mountains part of the Transverse Ranges Province of southern California. The generally east-striking structural grain characteristic of the crystalline rocks of much of the San Gabriel Mountains is apparent, but not well developed in the Telegraph Peak quadrangle. Here, the east-striking structural grain is somewhat masked by the northwest-striking grain associated with the San Andreas Fault zone. 
Faults within the quadrangle include northwest-striking, right-lateral strike-slip faults of the San Andreas system. The active San Andreas Fault, located in the northern part of the quadrangle, dominates the younger structural elements. North of the San Andreas Fault is the inactive Cajon Valley Fault that was probably an early strand of the San Andreas system. It was active during deposition of the middle Miocene Cajon Valley Formation. South of the San Andreas, the Punchbowl Fault, which is probably a long-abandoned segment of the San Andreas Fault (Matti and Morton, 1993), has a sinuous trace apparently due to compression in the eastern San Gabriel Mountains that post-dates displacement on the fault. The Punchbowl Fault separates two major subdivisions of the Mesozoic Pelona Schist and is left-laterally offset by a northeast-striking fault in the northwestern part of the quadrangle. Within the Punchbowl Fault zone is a thin layer of highly deformed basement rock, which is clearly not part of the Pelona Schist. To the southeast, in the Devore quadrangle, this included basement rock attains a thickness of several hundred feet. Along strike to the northwest, Tertiary sedimentary rocks are included within the fault zone. South of the Punchbowl Fault are several arcuate (in plan) faults that are part of an antiformal schuppen-like fault complex of the eastern San Gabriel Mountains. Most of these arcuate faults are reactivated and deformed older faults, and probably include the eastern part of the San Gabriel Fault.

The Vincent Thrust of late Cretaceous or early Tertiary age separates the Pelona Schist in the lower plate from a heterogeneous basement complex in the upper plate. Immediately above the Vincent Thrust is a variable thickness of mylonitic rock generally interpreted as a product of displacement on the thrust. The upper plate includes two Paleozoic units, a schist and gneiss sequence and a schist, quartzite, and marble metasedimentary sequence. Both sequences are thrust over the Mesozoic Pelona Schist along the Vincent Thrust, and intruded by Tertiary (late Oligocene) granitic rocks, granodiorite of Telegraph Peak, that also intrude the Vincent Thrust. The Pelona Schist consists mostly of greenschist to amphibolite metamorphic grade meta-basalt (greenschist and amphibolite) and meta-graywacke (siliceous and white mica schist), with minor impure quartzite and marble, in which all primary structures have been destroyed and all layering transposed. Cretaceous granitic rocks, chiefly tonalite, intrude the schist and gneiss sequence, but not the Pelona Schist or the Vincent Thrust.

North of the San Andreas Fault, bedrock units consist of undifferentiated Cretaceous tonalite, here informally named tonalite of Circle Mountain, with some included small boldies of gneiss and marble. These basement rocks are the westward continuation of rocks of the San Bernardino Mountains and not rocks of the San Gabriel Mountains south of the San Andreas Fault. Also north of the San Andreas Fault are the Oligocene Vaqueros Formation, middle Miocene Cajon Valley Formation, and Pliocene rocks of Phelan Peak. The latter two formations are divided into several conglomerate and arkosic sandstone subunits. In the northeastern corner of the quadrangle, the rocks of Phelan Peak are unconformably overlain by the Quaternary Harold Formation and Shoemaker Gravel. Quaternary units ranging from early Pleistocene to recent are mapped, and represent alluvial fan, landslide, talus, and wash environments.

The geologic map database contains original U.S. Geological Survey data generated by detailed field observation and by interpretation of aerial photographs. This digital Open-File map supercedes an older analog Open-File map of the quadrangle, and includes extensive new data on the Quaternary deposits, and revises some fault and bedrock distribution within the San Gabriel Mountains. The digital map was compiled on a base-stable cronoflex copy of the Telegraph 7.5' topographic base and then scribed. This scribe guide was used to make a 0.007 mil blackline clear-film, from which lines and point were hand digitized. Lines, points, and polygons were subsequently edited at the USGS using standard ARC/INFO commands. Digitizing and editing artifacts significant enough to display at a scale of 1:24,000 were corrected. Within the database, geologic contacts are represented as lines (arcs), geologic units as polygons, and site-specific data as points. Polygon, arc, and point attribute tables (.pat, .aat, and .pat, respectively) uniquely identify each geologic datum. Purpose: 
The data set for the Telegraph 7.5' quadrangle was prepared under the U.S. Geological Survey Southern California Areal Mapping Project (SCAMP) and the California Division of Mines as part of an ongoing effort to develop a regional geologic framework of southern California, and to utilize a Geographical Information System (GIS) format to create regional digital geologic databases. These regional databases are being developed as contributions to the National Geologic Map Database of the National Cooperative Geologic Mapping Program of the USGS.

The digital geologic map database for the Telegraph 7.5' quadrangle has been created as a general-purpose data set that is applicable to other land-related investigations in the earth and biological sciences. For example, the U.S. Forest Service, San Bernardino National Forest, may use the map and database as a basic geologic data source for soil studies, mineral resource evaluations, road building, biological surveys, and general forest management. The database is not suitable for site-specific geologic evaluations at scales greater than 1:24,000 $(1 \mathrm{in}=$ 2,000 ft).

Time_Period_of_Content:

Time_Period_Information:

Range_of_Dates/Times:

Beginning_Date: 19740401

Ending_Date: 19810801

Currentness_Reference: New data and previously published data

Status:

Progress: Complete

Maintenance_and_Update_Frequency: As needed

Spatial_Domain:

Bounding_Coordinates:

West_Bounding_Coordinate: -117.6250927

East_Bounding_Coordinate: -117.4999073

North_Bounding_Coordinate: 34.37499995

South_Bounding_Coordinate: 34.24998407

Keywords:

Theme:

Theme_Keyword_Thesaurus: None

Theme_Keyword: geologic map

Theme_Keyword: geology

Theme_Keyword: bedrock geology

Theme_Keyword: surficial geology

Theme_Keyword: San Andreas Fault

Theme_Keyword: San Jacinto Fault

Theme_Keyword: San Gabriel Mountains

Theme_Keyword: Pelona Schist

Place:

Place_Keyword_Thesaurus: None

Place_Keyword: California

Place_Keyword: San Bernardino County

Place_Keyword: Telegraph 7.5' quadrangle

Access_Constraints: None

Use_Constraints:

The Telegraph 7.5' geologic-map database should be used to evaluate and understand the geologic character of the Telegraph 7.5' quadrangle as a whole. The data should not be used for purposes of site-specific land-use planning or site-specific geologic evaluations. The database is sufficiently detailed to identify and characterize geologic materials and structures. However, 
it is not sufficiently detailed for site-specific determinations.

Use of this digital geologic map database should not violate the spatial resolution of the data. Although the digital form of the data removes the constraint imposed by the scale of a paper map, the detail and accuracy inherent in map scale are also present in the digital data. The fact that this database was compiled and edited at a scale of 1:24,000 means that higher resolution information may not have been uniformly retained in the dataset. Plotting at scales larger than 1:24,000 will not yield greater real detail, although it may reveal fine-scale irregularities below the intended resolution of the database. Similarly, although higher resolution data is incorporated in parts of the map, the resolution of the combined output will be limited by the lower resolution data.

Point_of_Contact:

Contact_Information:

Contact_Person_Primary:

Contact_Person: Douglas M. Morton

Contact_Organization: U.S. Geological Survey, Western Region, Earth Surface Processes Team

Contact_Position: Project geologist

Contact_Address:

Address_Type: mailing address

Address:

U.S. Geological Survey

Department of Earth Science

University of California, Riverside

City: Riverside

State_or_Province: California

Postal_Code: 92521

Country: United States of America

Contact_Voice_Telephone: (909) 276-6397

Contact_Facsimile_Telephone: (909) 276-6295

Contact_Electronic_Mail_Address: scamp@usgs.gov

Browse_Graphic:

Browse_Graphic_File_Name: http://geopubs.wr.usgs.gov/open-file/of01-293/images/tel_browse.jpg

Browse_Graphic_File_Description:

Non-navigable .jpg image of the geologic map, topographic base, Correlation of Map Units, Description of Map Units and key to point and line symbols.

Browse_Graphic_File_Type: .jpg

Browse_Graphic:

Browse_Graphic_File_Name: http://geopubs.wr.usgs.gov/open-file/of01-293/images/tel_map.pdf

Browse_Graphic_File_Description:

Navigable portable document file (.pdf) image of the geologic map, topographic base, Correlation of Map Units, Description of Map Units and key to point and line symbols.

Browse_Graphic_File_Type: .pdf

Data_Set_Credit:

Technical review by Michael Kennedy led to significant improvements that eventually were reflected in aspects of the database, the plot file, and in the description of the geologic units of the Telegraph $7.5^{\prime}$ quadrangle.

Geologic mapping and digital preparation of this report were sponsored jointly by (1) the National Cooperative Geologic Mapping Program of the U.S. Geological Survey, (2) the California Division of Mines and Geology, and (3) the Southern California Areal Mapping Project (SCAMP). In our digital preparation of the data set, carried out in the SCAMP Geographic Information System laboratory at the University of California, Riverside by Gregory Morton, and in the USGS Geographic Information System laboratory of the Mineral Resources Program of the U.S.

Geological Survey in Spokane, Washington by Pamela M. Cossette, we received valuable assistance 
from Rachel Alvarez in Riverside, California, and from Paul C. Hyndman in Spokane, Washington.

Native_Data_Set_Environment:

SunOS, 5.7, sun4u UNIX

ARC/INFO version 7.2.1

Cross_Reference:

Citation_Information:

Originator: D.M. Morton

Publication_Date: 1976

Title:

Geologic map of the Cucamonga fault zone between San Antonio Canyon and Cajon Creek, southern

California

Edition: Version 1.0

Geospatial_Data_Presentation_Form: paper map

Series_Information:

Series_Name: U.S. Geological Survey Open-File Report

Issue_Identification: USGS OF 76-726

Publication_Information:

Publication_Place: Menlo Park, California

Publisher: U.S. Geological Survey

Data_Quality_Information:

Attribute_Accuracy:

Attribute_Accuracy_Report:

Geologic-map units in the Telegraph quadrangle database were described using standard field methods. Consistent with these methods, the database author has assigned standard geologic attributes to geologic lines, points, and polygons identified in the database.

Nation-wide geologic-map accuracy standards have not been developed and adopted by the U.S. Geological Survey and other earth-science entities. Until such standards are adopted, the SCAMP project has developed internal map-accuracy standards for 1:24,000-scale geologic maps produced by the project.

Geologic lines and points on 1:24,000 scale geologic maps are judged to meet SCAMP's internal map-accuracy standards if they are located to within 15 meters, relative to topographic or cultural features on the base map.

Lines and points that meet (or may not meet) this SCAMP internal map-accuracy standard are identified both in the digital database and on derivative geologic-map plots. Within the database, line and point data that are judged to meet the SCAMP internal map-accuracy standard are denoted by the attribute code .MEE. (meets) in the appropriate data table; line and point data that may not meet the SCAMP internal map-accuracy standard are denoted by the attribute code .MNM. (may not meet).

On any derivative geologic-map plot, line data that are judged to meet the SCAMP internal map-accuracy standard are denoted by solid lines; line data that may not meet the SCAMP internal map-accuracy standard are denoted by dashed or dotted lines. There is no cartographic device for denoting the map-accuracy for geologic-point data (eg. symbols representing bedding, foliation, lineations, etc.).

Logical_Consistency_Report:

Polygon and chain-node topology present.

The areal extent of the map is represented digitally by an appropriately projected (Polyconic projection), mathematically generated box. Consequently, polygons intersecting the lines that 
comprise the map boundary are closed by that boundary. Polygons internal to the map boundary are completely enclosed by line segments which are themselves a set of sequentially numbered coordinate pairs. Point data are represented by coordinate pairs.

\section{Completeness_Report:}

The geologic map and digital database of the Telegraph 7.5' quadrangle contain new data that have been subjected to rigorous review and are a substantially complete representation of the current state of knowledge concerning the geology of the quadrangle.

Positional_Accuracy:

Horizontal_Positional_Accuracy:

Horizontal_Positional_Accuracy_Report:

The maximum transformation RMS error acceptable for 7.5' quadrangle transformation and data input is 0.003 (7.6 meters). Horizontal positional accuracy was checked by visual comparison of hard-copy plots with base-stable source data.

Lineage:

Process_Step:

Process_Description: Field mapping and aerial photograph interpretation; iterative process (D.M. Morton).

Process_Date: 1977 to 1978 and 1988 to 1989

Process_Step:

Process_Description: Aerial photograph interpretation and limited field checking; iterative process (D.M. Morton).

Process_Date: 1989

Process_Step:

Process_Description:

Transfer of geologic linework and point data from field maps and aerial photographs to a scale-stable cartographic base of quadrangle (scribeguide) (D.M. Morton).

Process_Date: 1978 and 1989

Process_Step:

Process_Description: Description of Map Units and Correlation of Map Units (D.M. Morton).

Process_Date: 1997

Process_Step:

Process_Description:

The geologic map information was hand digitized from a clear-film, right-reading, 0.007 mil thickness, base-stable blackline positive (made by contact photograph from a scribeguide) of the authors-prepared geologic map at 1:24,000 scale (G. Morton).

Process_Date: 1997

Process_Step:

Process_Description:

ARC/INFO database established; cleanup of digitizing artifacts; polygon, arc, and point attribute tables established using model developed for SCAMP coverages. Digitizing and editing artifacts significant enough to display at a scale of 1:24,000 were corrected (P.M. Cossette).

Process_Date: 1997, 1998 and 2001

Process_Step:

Process_Description:

First draft of metadata created by Cossette using FGDCMETA.AML ver. 1.2 05/14/98 on ARC/INFO data set /pool5/c/cossette2/telegraph/tel_geo420a

Process_Date: 20010420

Spatial_Data_Organization_Information:

Direct_Spatial_Reference_Method: Vector

Point_and_Vector_Object_Information:

SDTS_Terms_Description:

SDTS_Point_and_Vector_Object_Type: Point

Point_and_Vector_Object_Count: 720 


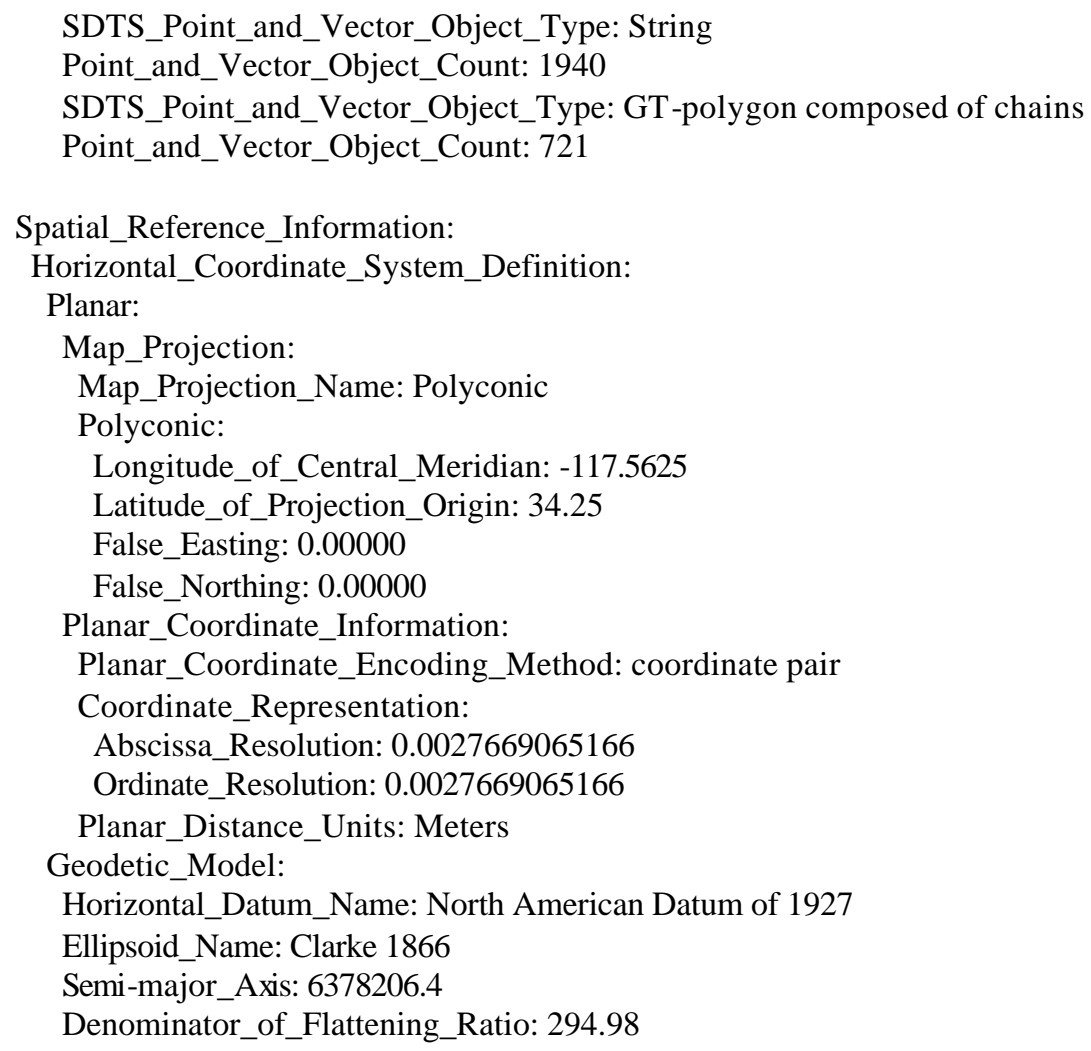

Geologic data represented by line entities and the polygons they delineate are contained in the coverage TEL_GEO. For display purposes, the geology coverage contains two annotation subclasses: anno.geo contains unit labels, and anno.fault contains formal, fault names.

Geological point data includes site-specific information describing the types and the orientation of bedding, foliation, and lineations. One annotation subclass is included in the geologic points coverage, TEL_STR which displays displays the respective dip and plunge values associated with individual point data.

Entity_and_Attribute_Detail_Citation:

A complete description of the polygon, line, and point data coding schemes is available in U.S. Geological Survey Open-File Reports OFR 97-859, OFR 97-860, and OFR 97-861 (full source citations follow):

Matti, J.C., Miller, F.K., Powell, R.E., Kennedy, S.A., Bunyapanasarn, T.P., Koukladas, Catherine, Hauser, R.M., and Cossette, P.M., 1997b, Geologic-point attributes for digital geologic-map databases produced by the Southern California Areal Mapping Project (SCAMP), Version 1.0: U.S.Geological Survey Open-File Report 97-859

Matti, J.C., Miller, F.K., Powell, R.E., Kennedy, S.A., and Cossette, P.M., 1997c, 
Geologic-polygon attributes for digital geologic-map databases produced by the Southern California Areal Mapping Project (SCAMP), Version 1.0: U.S.Geological Survey Open-File Report $97-860$

Matti, J.C., Powell, R.E., Miller, F.K., Kennedy, S.A., Ruppert, K.R., Morton, G.L., and Cossette, P.M., 1997a, Geologic-line attributes for digital geologic-map databases produced by the Southern California Areal Mapping Project (SCAMP), Version 1.0: U.S.Geological Survey Open-File Report 97-861

Detailed_Description:

Entity_Type:

Entity_Type_Label: tel_geo.pat

Entity_Type_Definition:

Geologic units (LABL) and their corresponding names (NAME) identified in the Telegraph

7.5'quadrangle

Attribute:

Attribute_Label: LABL

Attribute_Definition: geologic map unit label, in plain text

Attribute_Domain_Values:

Enumerated_Domain:

Enumerated_Domain_Value: Kcm

Enumerated_Domain_Value_Definition: Tonalite of Circle Mountain

Enumerated_Domain:

Enumerated_Domain_Value: Kgd

Enumerated_Domain_Value_Definition: Ganodiorite

Enumerated_Domain:

Enumerated_Domain_Value: Kss

Enumerated_Domain_Value_Definition: Tonalite of San Sevaine Lookout

Enumerated_Domain:

Enumerated_Domain_Value: Mzpa

Enumerated_Domain_Value_Definition: Pelona Schist, amphibolite grade schist

Enumerated_Domain:

Enumerated_Domain_Value: Mzpg

Enumerated_Domain_Value_Definition: Pelona Schist, greenstone

Enumerated_Domain:

Enumerated_Domain_Value: Mzps

Enumerated_Domain_Value_Definition: Pelona Schist, muscovite schist

Enumerated_Domain:

Enumerated_Domain_Value: Pzm

Enumerated_Domain_Value_Definition: Metasedimentary rocks, undifferentiated

Enumerated_Domain:

Enumerated_Domain_Value: Pzs

Enumerated_Domain_Value_Definition: Schist and gneiss

Enumerated_Domain:

Enumerated_Domain_Value: Qh

Enumerated_Domain_Value_Definition: Harold Formation

Enumerated_Domain:

Enumerated_Domain_Value: Qls

Enumerated_Domain_Value_Definition: Very young landslide deposits

Enumerated_Domain:

Enumerated_Domain_Value: Qoa

Enumerated_Domain_Value_Definition: Old alluvial-valley deposits

Enumerated_Domain:

Enumerated_Domain_Value: Qofb

Enumerated_Domain_Value_Definition: Old alluvial-fan deposits, boulder gravel

Enumerated_Domain:

Enumerated_Domain_Value: Qofg 
Enumerated_Domain_Value_Definition: Old alluvial-fan deposits, gravel

Enumerated_Domain:

Enumerated_Domain_Value: Qsh

Enumerated_Domain_Value_Definition: Shoemaker Gravel

Enumerated_Domain:

Enumerated_Domain_Value: Qvof

Enumerated_Domain_Value_Definition: Very old alluvial-fan deposits

Enumerated_Domain:

Enumerated_Domain_Value: Qvofg

Enumerated_Domain_Value_Definition: Very old alluvial-fan deposits, gravel

Enumerated_Domain:

Enumerated_Domain_Value: Qvols

Enumerated_Domain_Value_Definition: Very old landslide deposits

Enumerated_Domain:

Enumerated_Domain_Value: Qvolsa

Enumerated_Domain_Value_Definition: Very old landslide deposits, arenaceous

Enumerated_Domain:

Enumerated_Domain_Value: Qwb

Enumerated_Domain_Value_Definition: Very young wash deposits, boulder gravel

Enumerated_Domain:

Enumerated_Domain_Value: Qwg

Enumerated_Domain_Value_Definition: Very young wash deposits, gravel

Enumerated_Domain:

Enumerated_Domain_Value: Qyfg

Enumerated_Domain_Value_Definition: Young alluvial-fan deposits, gravel

Enumerated_Domain:

Enumerated_Domain_Value: Qyfgb

Enumerated_Domain_Value_Definition: Young alluvial-fan deposits, gravel boulder

Enumerated_Domain:

Enumerated_Domain_Value: Qyls

Enumerated_Domain_Value_Definition: Young landslide deposits

Enumerated_Domain:

Enumerated_Domain_Value: Qyt

Enumerated_Domain_Value_Definition: Young talus deposits

Enumerated_Domain:

Enumerated_Domain_Value: Qywg

Enumerated_Domain_Value_Definition: Young wash deposits, gravel

Enumerated_Domain:

Enumerated_Domain_Value: Tcv1

Enumerated_Domain_Value_Definition: Rocks of Cajon Valley, Unit 1

Enumerated_Domain:

Enumerated_Domain_Value: Tcv2

Enumerated_Domain_Value_Definition: Rocks of Cajon Valley, Unit 2

Enumerated_Domain:

Enumerated_Domain_Value: Tcv3

Enumerated_Domain_Value_Definition: Rocks of Cajon Valley, Unit 3

Enumerated_Domain:

Enumerated_Domain_Value: Tcv5

Enumerated_Domain_Value_Definition: Rocks of Cajon Valley, Unit 5

Enumerated_Domain:

Enumerated_Domain_Value: Tcv5a

Enumerated_Domain_Value_Definition: Rocks of Cajon Valley, Unit 5a

Enumerated_Domain:

Enumerated_Domain_Value: Tpp1

Enumerated_Domain_Value_Definition: Phelan Peak deposits of Weldon (1984), Unit 1

Enumerated_Domain: 
Enumerated_Domain_Value:Tpp2

Enumerated_Domain_Value_Definition: Phelan Peak deposits of Weldon (1984), Unit 2

Enumerated_Domain:

Enumerated_Domain_Value: Tpp3

Enumerated_Domain_Value_Definition: Phelan Peak deposits of Weldon (1984), Unit 3

Enumerated_Domain:

Enumerated_Domain_Value: Ttp

Enumerated_Domain_Value_Definition: Granodiorite of Telegraph Peak

Enumerated_Domain:

Enumerated_Domain_Value: Tv

Enumerated_Domain_Value_Definition: Vaqueros Formation

Enumerated_Domain:

Enumerated_Domain_Value: fz

Enumerated_Domain_Value_Definition: Crushed rock in fault zones

Enumerated_Domain:

Enumerated_Domain_Value: gn

Enumerated_Domain_Value_Definition: Gneiss

Enumerated_Domain:

Enumerated_Domain_Value: $m$

Enumerated_Domain_Value_Definition: Marble

Attribute:

Attribute_Label: PLABL

Attribute_Definition:

Coded geologic map unit label used to generate plot labels with relevant stratigraphic symbols.

The geologic units with LABL designating Mesozoic (Mz), and Paleozoic (Pz), have keystroke

substitute characters, \} and | respectively, that call their corresponding symbols from the

Geoage Font Group. Geologic map unit labels will plot on derivative map plots with appropriate stratigraphic symbols if PLABL is used as the source for unit labels. The Geoage Font Group is accessed through geofont.txt. The GeoAge Font Group and relevant information are available by anonymous FTP from:

Server: onyx.wr.usgs.gov

Attribute:

Attribute_Label: SHDPS

Attribute_Definition: polygon color (as integer value) from shadeset scamp2.shd (included in the data package)

Attribute:

Attribute_Label: SHDFIL

Attribute_Definition: polygon fill pattern (as integer value) from shadeset geology2.shd

Attribute:

Attribute_Label: NAME

Attribute_Definition: Geologic name of map unit (see list under LABL attribute)

Detailed_Description:

Entity_Type:

Entity_Type_Label: tel_geo.aat

Entity_Type_Definition:

Geologic features such as contacts and faults that bound rock-unit polygons (a complete

description of each line type is available in the data table, lines.rel.)

Attribute:

Attribute_Label: L-TAG

Attribute_Definition:

Coded alpha-numerical symbol that relates arc to definition of line type in dictionary look-up

table (lines.rel). For description of attributes in line classification dictionary, refer to

USGS Open-File Report 97-861 (see Entity_and_Attribute_Detail_Citation)

Attribute_Domain_Values:

Enumerated_Domain:

Enumerated_Domain_Value: C1 
Enumerated_Domain_Value_Definition: Contact, generic, certain, location meets map accuracy standard Enumerated_Domain:

Enumerated_Domain_Value: C17

Enumerated_Domain_Value_Definition: Contact, landslide, certain, location meets map accuracy standard

Enumerated_Domain:

Enumerated_Domain_Value: C18 standard

Enumerated_Domain_Value_Definition: Contact, landslide, certain, location may not meet map accuracy

Enumerated_Domain:

Enumerated_Domain_Value: C19

Enumerated_Domain_Value_Definition: Contact, landslide, inferred, location may not meet map accuracy standard

Enumerated_Domain:

Enumerated_Domain_Value: C25

Enumerated_Domain_Value_Definition: Contact, landslide, crown scarp, certain, location meets map accuracy standard

Enumerated_Domain:

Enumerated_Domain_Value: C29

Enumerated_Domain_Value_Definition: Contact, sedimentary, certain, location meets map accuracy standard

Enumerated_Domain:

Enumerated_Domain_Value: C30

Enumerated_Domain_Value_Definition: Contact, sedimentary, certain, location may not meet map accuracy standard

Enumerated_Domain:

Enumerated_Domain_Value: C31

Enumerated_Domain_Value_Definition: Contact, sedimentary, inferred, location may not meet map accuracy standard

Enumerated_Domain:

Enumerated_Domain_Value: C50

Enumerated_Domain_Value_Definition: Contact, igneous, location may not meet map accuracy standard

Enumerated_Domain:

Enumerated_Domain_Value: C51

Enumerated_Domain_Value_Definition: Contact, igneous, inferred, location may not meet map accuracy standard

Enumerated_Domain:

Enumerated_Domain_Value: C66

Enumerated_Domain_Value_Definition: Contact, metamorphic, certain, location may not meet map accuracy standard

Enumerated_Domain:

Enumerated Domain Value: C67

Enumerated_Domain_Value_Definition: Contact, metamorphic, inferred, location may not meet map accuracy standard

Enumerated_Domain:

Enumerated_Domain_Value: CL1

Enumerated_Domain_Value_Definition: Cartographic line, map boundary

Enumerated_Domain:

Enumerated_Domain_Value: F1

Enumerated_Domain_Value_Definition: Fault, high angle, slip unspecified, location meets map accuracy standard

Enumerated_Domain:

Enumerated_Domain_Value: F15

Enumerated_Domain_Value_Definition:

Fault, high angle, strike slip, left lateral, inferred, location may not meet map accuracy

standard

Enumerated_Domain:

Enumerated_Domain_Value: F177 

standard

Enumerated_Domain_Value_Definition: Fault, thrust, older over younger, certain, location meets map accuracy

Enumerated_Domain:

Enumerated_Domain_Value: F180

Enumerated_Domain_Value_Definition: Fault, thrust, older over younger, concealed, location may not meet map accuracy standard

Enumerated_Domain:

Enumerated_Domain_Value: F19

Enumerated_Domain_Value_Definition: Fault, high angle, slip unspecified, concealed, location may not meet map accuracy standard

Enumerated_Domain:

Enumerated_Domain_Value: F2

Enumerated_Domain_Value_Definition: Fault, high angle, right lateral strike slip, certain, location meets map accuracy standard

Enumerated_Domain:

Enumerated_Domain_Value: F20

Enumerated_Domain_Value_Definition:

Fault, high angle, right lateral strike slip, concealed, location may not meet map accuracy standard

Enumerated_Domain:

Enumerated_Domain_Value: F21

Enumerated_Domain_Value_Definition:

Fault, high angle, strike slip, left lateral, inferred, location may not meet map accuracy standard

Enumerated_Domain:

Enumerated_Domain_Value: F24

Enumerated_Domain_Value_Definition: Fault, high angle, oblique slip, inferred, location may not meet map accuracy standard

Enumerated_Domain:

Enumerated_Domain_Value: F3

Enumerated_Domain_Value_Definition:

Fault, high angle, left lateral strike slip, scarp, certain, location meets map accuracy

standard

Enumerated_Domain:

Enumerated_Domain_Value: F45

Enumerated_Domain_Value_Definition:

Fault, high angle, left lateral strike slip, questionable, inferred, location may not meet map

accuracy standard

Enumerated_Domain:

Enumerated_Domain_Value: F6

Enumerated_Domain_Value_Definition: Fault, high angle, oblique slip, certain, location meets map accuracy standard

Attribute:

Attribute_Label: L-SYMB

Attribute_Definition: stores appropriate line symbol value from the lineset geoscamp2.lin

Attribute:

Attribute_Label: L-NAME

Attribute_Definition: Formal name of fault

Detailed_Description:

Entity_Type:

Entity_Type_Label: tel_str.pat

Entity_Type_Definition:

Geological point data includes site-specific information describing the types and the orientation of bedding, foliation, and lineations. One annotation subclass is included in the geologic points coverage, TEL_STR and displays the respective dip and plunge values associated with individual point data. 
Attribute:

Attribute_Label: P-TAG

Attribute_Definition:

Coded alpha-numerical value that relates point entity to definition of point type in dictionary

INFO table, points.rel. For description of attributes in point classification dictionary, refer

to USGS Open-File Report 97-859 (see Entity_and_Attribute_Detail_Citation)

Attribute_Domain_Values:

Enumerated_Domain:

Enumerated_Domain_Value: B1

Enumerated_Domain_Value_Definition: Bedding, sedimentary, horizontal

Enumerated_Domain:

Enumerated_Domain_Value: B2

Enumerated_Domain_Value_Definition: Bedding, sedimentary, inclined

Enumerated_Domain:

Enumerated_Domain_Value: B4

Enumerated_Domain_Value_Definition: Bedding, sedimentary, vertical

Enumerated_Domain:

Enumerated_Domain_Value: B6

Enumerated_Domain_Value_Definition: Bedding, sedimentary, overturned

Enumerated_Domain:

Enumerated_Domain_Value: FN42

Enumerated_Domain_Value_Definition: Foliation, metamorphic, inclined

Enumerated_Domain:

Enumerated_Domain_Value: FN43

Enumerated_Domain_Value_Definition: Foliation, metamorphic, vertical

Enumerated_Domain:

Enumerated_Domain_Value: L22

Enumerated_Domain_Value_Definition: Lineation, metamorphic, aligned mineral grains

Attribute:

Attribute_Label: P-SYMB

Attribute_Definition: Coded integer value that relates point to cartographic point symbol in markerset geoscamp2.mrk

Attribute:

Attribute_Label: P-DIP

Attribute_Definition: Dip of planar feature

Attribute:

Attribute_Label: P-STRIKE

Attribute_Definition: Azimuthal strike of planar feature

Attribute:

Attribute_Label: P-DIPDIR

Attribute_Definition: Azimuthal direction of dip of planar feature

Attribute:

Attribute_Label: P-PLUNGE

Attribute_Definition: Plunge of linear feature

Attribute:

Attribute_Label: P-BEARING

Attribute_Definition: Azimuthal direction of plunge of linear feature

Detailed_Description:

Entity_Type:

Entity_Type_Label: tel_ldr.aat

Entity_Type_Definition: Annotation leaders

Attribute:

Attribute_Label: L-SYMB

Attribute_Definition: Coded integer value (1) that relates arcs to cartographic line symbol in lineset Distribution_Information:

Distributor: 


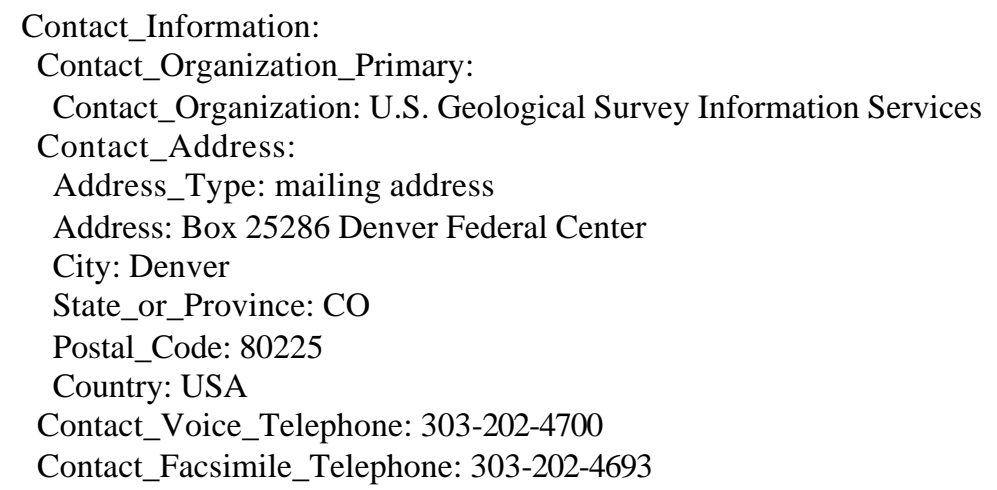

Distribution_Liability:

The U.S. Geological Survey (USGS) provides these geographic data "as is." The USGS makes no guarantee or warranty concerning the accuracy of information contained in the geographic data. The USGS further makes no warranties, either expressed or implied as to any other matter whatsoever, including, without limitation, the condition of the product, or its fitness for any particular purpose. The burden for determining fitness for use lies entirely with the user. Although these data have been processed successfully on computers at the USGS, no warranty, expressed or implied, is made by the USGS regarding the use of these data on any other system, nor does the fact of distribution constitute or imply any such warranty.

In no event shall the USGS have any liability whatsoever for payment of any consequential, incidental, indirect, special, or tort damages of any kind, including, but not limited to, any loss of profits arising out of use of or reliance on the geographic data or arising out of the delivery, installation, operation, or support by USGS.

This digital, geologic map database of the Telegraph Peak 7.5' quadrangle, 1:24,000 map-scale, and any derivative maps thereof, is not meant to be used or displayed at any scale larger than 1:24,000 (e.g., 1:12,000).

Metadata_Reference_Information:

Metadata_Date: 20010917

Metadata_Review_Date: 2001

Metadata_Contact:

Contact_Information:

Contact_Organization_Primary:

Contact_Organization: U.S. Geological Survey

Contact_Person: Pamela M. Cossette

Contact_Position: Geographer

Contact_Address:

Address_Type: mailing address

Address:

U.S. Geological Survey

West 904 Riverside Avenue

City: Spokane

State_or_Province: Washington

Postal_Code: 99201-1087

Country: USA

Contact_Voice_Telephone: 509-368-3123

Contact_Facsimile_Telephone: 509-368-3199

Contact_Electronic_Mail_Address: pcossette@usgs.gov

Metadata_Standard_Name: FGDC Content Standards for Digital Geospatial Metadata

Metadata_Standard_Version: Version of June 8, 1994

Metadata_Access_Constraints: none

Metadata_Use_Constraints: none 